\title{
Iminosugar 1-Deoxynojirimycin (DNJ) sebagai Antiviral Infeksi Virus Dengue
}

\author{
Muhammad Lutfi Adnan ${ }^{1 *}$ \\ ${ }^{1}$ Fakultas Kedokteran, Universitas Islam Indonesia, Yogyakarta-Indonesia \\ * corresponding author: lutfiadnan35@yahoo.co.id
}

\begin{abstract}
Dengue fever (DF), dengue hemorrhagic fever (DHF), and dengue shock syndrome (DSS) caused by the DENV virus are among the global problems regarding mosquito-borne viral infections. The DENV virus is transmitted through Aedes aegypti causing clinical manifestations that can cause critical illness for patients. The need for effective antiviral therapy is needed to treat DENV virus infections. 1-Deoxynojirimycin (DNJ), one of the many imino sugars found in mulberry leaves and several strains of bacteria, has potential as an antiviral against DENV virus infection. The antiviral activity of DNJ works as an inhibitor of the $\alpha$ glucosidase enzyme which is important in virus secretion so that it affects the infection rate. DNJ also has the effect of boosting the immune system to initiate an immune response to a viral infection. Further research is needed to develop DNJ as an effective antiviral DENV in the future.
\end{abstract}

Keywords: antiviral, dengue, iminosugar, therapy

\begin{abstract}
Abstrak-Dengue fever (DF), dengue hemorraghic fever (DHF), dan dengue shock syndrome (DSS) yang disebabkan oleh virus DENV merupakan salah satu permasalahan global mengenai infeksi virus. Virus DENV ditularkan melalui Aedes aegypti menyebabkan manifestasi klinis yang dapat menimbulkan kesakiatn kritis bagi pasien. kebutuhan terapi antiviral yang efektif diperlukan untuk mengobati infeksi virus DENV. 1-Deoxynojirimycin (DNJ), salah satu iminosugar yang banyak terdapat pada daun mulberry dan beberapa strain bakteri, memiliki potensi sebagai antiviral terhadap infeksi virus DENV. Aktivitas antiviral DNJ bekerja sebagai penghambat enzim $\alpha$-glukosidase yang penting dalam sekresi virus sehingga mempengaruhi tingkat infeksi. DNJ juga memiliki efek meningkatkan sistem imun untuk menginisiasi respon imun terhadap infeksi virus. Penelitian lebih lanjut diperlukan untuk mengembangkan DNJ sebagai antiviral DENV yang efektif di masa depan.
\end{abstract}

Kata kunci: antiviral, dengue, iminosugar, therapy

\section{PENDAHULUAN}

Virus DENV yang merupakan penyebab dari dengue fever (DF), dengue hemorraghic fever (DHF), dan dengue shock syndrome (DSS) merupakan salah satu permasalahan mayor dalam kesehatan publik dari mosquito-borne viral disease [1]. Setiap tahunnya 390 juta orang terinfeksi dengue, dengan 294 juta orang atau 75\% dari total orang terinfeksi dengue mengalami infeksi asimptomatik dan 96 juta orang atau $25 \%$ orang mengalami infeksi simptomatik. Lima ratus ribu orang per tahun memerlukan perawatan di rumah sakit hingga mencapai tingkat keparahan yang tinggi. Korban jiwa akibat infeksi dengue per tahun mencapai 25 ribu kematian, dan kebanyakan terjadi pada anak-anak [2].

Manusia merupakan host bagi virus dengue [3]. Virus dengue ditransmisikan oleh nyamuk betina Aedes aegypti melalui liur nyamuk ketika menghisap darah. Nyamuk Aedes aegypti merupakan spesies yang hidup di daerah tropis dan subtropis, namun juga dapat ditemukan di daerah utara selama musim panas. Nyamuk tersebut dapat ditemukan di daerah pada ketinggian di bawah 1000 meter di atas ketinggian laut. Aktivitas perkembangbiakan nyamuk tersebut berada di daerah genangan air seperti bekas kaleng atau container [4]. Aedes aegypti merupakan vektor yang efisien dalam penyebaran virus karena dapat menggigit berkali-kali pada korban sebelum dapat melengkapi oogenesis [5].

Pengobatan saat ini masih terbatas pada pengobatan yang berdasarkan tingkat keparahan infeksi, yang mana pada kondisi tertentu dapat meningkatkan risiko kematian pasien [2]. Pengobatan untuk infeksi viral saat ini terbagi menjadi dua kelas, yaitu direct-acting drugs yang bekerja dengan menargetkan salah satu komponen virus dan host-direct drugs yang bekerja pada penargetan inang yang menjadi tempat replikasi virus. Penggunaan obat dari direct-acting telah banyak menimbulkan resistensi, sehingga pengembangan antiviral host- 
direct drugs memiliki prospek dalam pengembangan obat antiviral [6,7]. Pengembangan antiviral melalui host-direct class menjadi tantangan karena kebutuhan untuk memastikan toksiksitas selektivitas menuju virus dan permasalahan mutasi virus yang dapat menimbulkan resistensi antiviral [8].

Iminosugar, yang merupakan analog gula banyak didapatkan melalui ekstraksi tanaman ataupun mikroba maupun disintesiskan mengandung banyak varietas untuk perkembangan obat untuk berbagai macam penyakit [9]. Salah satu bentuk derivat dari iminosugar, 1-deoxynojirimicyn, memiliki aktivitas antiviral terhadap infeksi virus seperti hepatitis B virus (HBV), hepatitis C virus (HCV), virus Ebola, virus Influenza A, dan virus Dengue [10]. Tujuan dari review ini adalah untuk membahas aktivitas antiviral dari iminosugar 1deoxynojirimicyn sebagai antivital potensial terhadap infeksi dengue.

\section{METODE}

Pencarian literatur secara komprehensif dilakukan pada April-Juni 2020 dengan menggunakan mesin pencari Google Scholar, Pubmed, dan ScienceDirect. Pencarian literatur yang dilakukan menggunakan kombinasi kata kunci antiviral, dengue, viral infection, iminosugar, dan 1-deoxynojirymicyn. Kriteria inkulsi yang digunakan adalah artikel berupa fulltext berbahasa Inggris dan Indonesia dengan publikasi kurang dari 10 tahun. Kriteria eksklusi yang digunakan adalah artikel non-fulltext, bukan berbahasa Inggris atau Indonesia dan dipublikasikan lebih dari 10 tahun yang lalu.

\section{BAHASAN}

\section{Patogenesis Infeksi Virus Dengue}

Infeksi dengue pada manusia diakibatkan oleh virus dengue (DENV), virus rantai tunggal RNA yang terbagi dalam empat serotipe, yaitu DENV-1 sampai DENV-4. DENV berasal dari genus flavivirus dengan famili Flaviviridae. Partikel virus berbentuk bulat dengan diameter $50 \mathrm{~nm}$ yang mengandung tiga protein struktural, lapisan bilayer dan genome rantai tunggal RNA positif yang tersusun dalam tiga protein struktural dengan tujuh protein non structural [11]. Struktur virus dewasa terdiri dari tiga protein struktural, yaitu protein kapsid C, protein membran $M$, dan protein pembungkus $E$ dan tujuh protein non struktural yaitu NS1, NS2A, NS2B, NS3, NS4A, NS4B dan NS5. Lapisan nukleuskapsid visur terdiri dari lipid yang dibentuk dari 180 salinan protein $\mathrm{M}$ dan E. Protein E memiliki tiga struktur domain yang berbeda dimana domain I terletak diantara domain II yang berupa domain homodimerisasi dan domain III berupa imunoglobulin-like domain III [12].

DENV yang bereplikasi dalam midgut nyamuk dan ditularkan melalui saliva nyamuk Aedes aegypti ketika menghisap darah manusia. DENV bekerja dengan menargetkan sel fagosit mononuklear seperti monosit, makrofag dan sel dendritik termasuk sel Langerhans pada kulit. Setelah masuk ke dalam sel, virus akan memasuki masa inkubasi selama 4-7 hari sebelum kemudian menimbulkan manifestasi klinis [13]. Virus kemudian menginfeksi sel dan melepaskan nukleokapsid untuk melepaskan RNA agar dapat bereplikasi. Protein M dan E kemudian membentuk heterodimer di retikulum endoplasma (RE) dan berikatan dengan protein $\mathrm{C}$ untuk membentuk virus imatur. Selama transpor dari RE menuju badan golgi, virus imatur berinteraksi dengan furin membentuk virus dewasa sehingga siap dilepas dari sel inangnya [12]. 


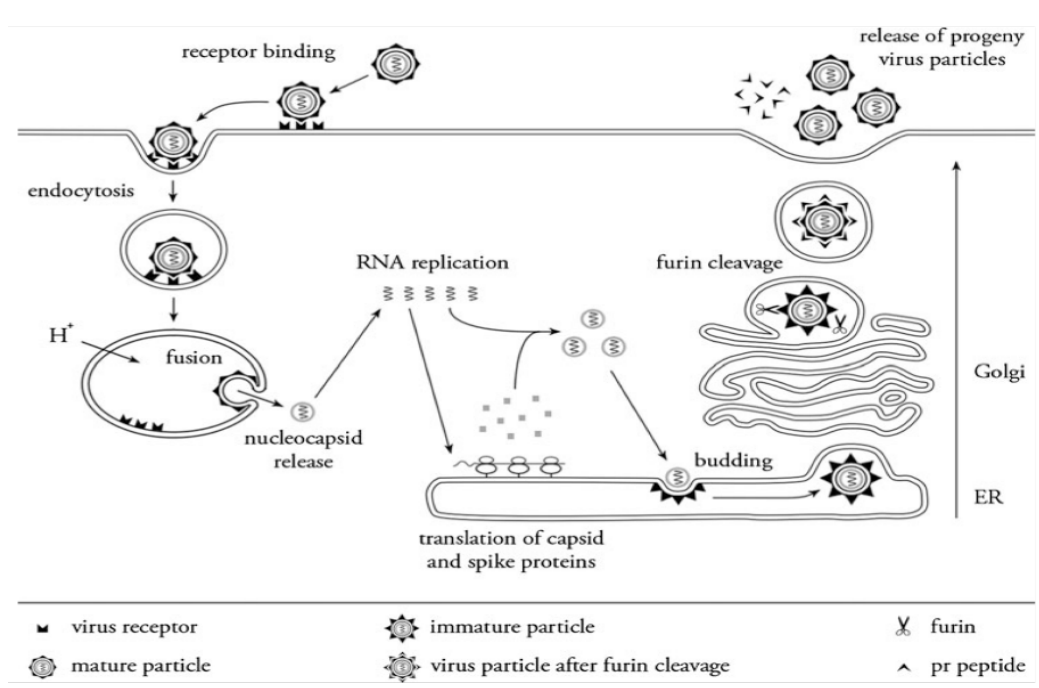

Gambar 1. Mekanisme virus DENV menginfeksi sel inang [12].

Protein di RE yang paling banyak disintesis adalah glikoprotein. Proses glikosilasi yang paling umum pada RE eukariot berupa glikosilasi $\mathrm{N}$-linked. Proses glikosilasi glikoprotein di RE melibatkan dua enzim pembelahan RE yaitu $\alpha$-glukosidase I dan II yang diperlukan untuk pelipatan dan fungsi yang tepat antara glikoprotein dengan pengikat protein seperti kaperon, kalneksin dan kalretikulin sebelum melakukan transpor dari RE ke badan golgi [10]. Peran penting dari enzim $\alpha$-glukosidase I dan II dalam proses pembentukan ampol luar untuk glikoprotein luar sel virus. Amplop luar ini memiliki fungsi pengenalan sel inang, fusi membran dan masuknya genom virus ke dalam sel, sehingga dapat menjadi target penghambatan siklus hidup sel virus dalam inang [14].

Infeksi DENV akan menstimulasi respons imun bawaan dan merekrut berbagai jenis sitokin seperti interferon tipe I dan faktor-faktor kemotaktik seperti migration inhibitor factor (MIF), monocyte chemotactic factor (MCF) dan interleukin-8/IL-8. DENV juga akan menstimulasi migrasi sel dendritik melalui inisiasi produksi matriks metalloprotease-2/MMP2 dan MMP-9 yang berperan dalam migrasi sel dendritik ke situs limfonodi lokal yang terinfeksi. Migrasi sel dendritik dan monosit/makrofag ke lokasi infeksi akan menstimulus dari produksi sitokin proinflamasi, yang mana bersama MMP-9 akan meningkatkan permeabilitas vaskular dan menimbulkan kebocoran plasma yang merupakan salah satu manifestasi klinis demam berdarah dengue. DENV juga akan menginduksi aktivasi populasi sel imune bawaan sel natural killer/NK dan NK-like untuk memproduksi sitokin proinflamasi TNF- $\alpha$, IFN- $\gamma$ dan IL-4. Meskipun berperan dalam menghambat replikasi sel virus, namun aktivitas sitokin proinflamasi juga berisiko menimbulkan cedera jaringan organ, terutama pada hepar, dan koagulopati. DENV juga memicu perubahan pada reseptor vascular endothelial growth factor-A/VEGF-A, dimana DENV akan meningkatkan responsifitas VEGF-A untuk memicu kebocoran plasma [15].

Manifestasi klinis lainnya dari infeksi virus dengue, trombositopenia, dan leukopenia yang terjadi pada fase awal infeksi, berhubungan juga dengan aktivitas supresi sumsum tulang terutama pada hematopoietic stem cell dan megakaryocite yang berdampak pada disregulasi hematologik. Kejadian trombosiotpenia dan leukopenia yang berhubungan dengan supresi sumsum tulang oleh infeksi DENV berkorelasi dengan tingkat keparahan infeksi dengue yang ditemukan pada kasus demam berdarah dengue [16]. Kemampuan supresi di sumsum tulang juga memungkinkan virus untuk bereplikasi dan bertahan dalam platelet dan sel darah merah yang berasal dari sumsum tulang, dimana pada beberapa kasus ditemukan komponen RNA virus yang tersimpan dalam dalam platelet dan sel darah merah pasien [17]. Akibatnya, kejadian penularan DENV melalui transfusi darah dari pasien dengan riwayat infeksi dengue harus diwaspadai pada beberapa kasus transfuse [18]. 


\section{Potensi Pemanfaatan Iminosugar 1- Deoxynojirimycin (DNJ)}

1- Deoxynojirimycin/DNJ (C6H12NO4) dengan nama kimia 3,4,5-trihydroxy-2hydroxymethyltetrahydropyridine merupakan salah satu alkaloid turunan iminosugar. Strukur iminosugar merupakan analog dari glukosa, dimana cincin atomoksigen digantikan dengan cincin grup imino [19]. Kandungan DNJ banyak didapatkan dari ekstraksi daun mulberry, bunga matahari, dan beberapa strain bakteri seperti Bacillus, Streptomyces, Actinoplanes, dan Flavobacterium saccharophillium. DNJ didapatkan melalui ekstraksi dari pohon mulberry dan ulat sutra yang banyak mengonsumsi dari daun mulberry, fermentasi oleh bakteri Bacillus dan Streptomyces [20].

DNJ telah banyak diteliti karena memiliki efek aktivitas antihyperglikemik dan antiobesitas yang bermanfaat dalam pengobatan diabates mellitus [21]. Aktivitas antihiperglikemik DNJ melalui penghambatan absorbsi dan pencernaan dari maltosa yang terdapat dalam kandungan beras [22]. DNJ bekerja dengan mengubah ekspresi transpor $\mathrm{Na}^{+} / \mathrm{K}^{+}$-ATP, SGLT1 dan GLUT2 yang banyak diekspresikan di saluran usus. DNJ akan mengurangi penyerapan jumlah glukosa yang dikonsumsi dan mengkatalis reaksi glikolisis dan glukoneogenesis dari metabolisme glukosa yang ada di hepar melalui peningkatan glukokinase (GK), phosphofructokinase (PFK), pyrivate kinase (PK), phosphoenolpyruvate carboxykinase (PEPCK) and glucose-6-phosphatase (G-6-Pase) [23]. DNJ juga memengaruhi pembentukan adiposa, yang mana memengaruhu terjadinya obesitas. DNJ dapat berefek pada sel preeadposit dengan mengurangi ekspresi aP2, PPARg dan Pref-1, sementara mengatur ekspresi dari UCP1, PRDM16 dan TMEM26, disertai dengan penurunan deposisi lipid. DNJ memengaruhi dengan mengurangi pembentukan adiposa putih untuk menyimpan energi dan terbentuknya sel adiposa krem untuk penurunan berat badan [24].

DNJ telah banyak diteliti mengenai potensi aktivitas antiviralnya terhadap beberapa infeksi virus. DNJ telah diteliti karena kemampuannya menghambat sekresi dan replikasi virus dari sel inang, dimana ditemukan DNJ dapat merusak proses pematangan virus di reticulum endoplasma sel host melalui misfolding glikoprotein pada virus [25]. Pemberian antiviral tersebut akan berdampak pada sistem imunitas tubuh melalui pembentukan antibodi IgG dan IgM dengan tingkat yang tidak jauh berbeda pada subjek yang terinfeksi. Melalui penghambatan sekresi virus dan pembentukan antibodi kekebalan tubuh, infeksi virus dapat tidak sampai mengalami perburukan dan menimbulkan dampak yang berbahaya bagi tubuh sekaligus membentuk protektivitas bagi tubuh pasca infeksi [26]. Temuan ini mendukung banyak studi mengenai potensi DNJ sebagai antiviral yang berpotensi bagi pengobatan infeksi virus seperti HIV, HCV dan DENV [27].

Penggunaan DNJ sebagai antiobesitas dan antihiperglikemik diketahui memiliki efek samping yang lebih sedikit dibandingkan dengan acarbose, obat anti-diabetik yang juga zat penghambat enzim $\alpha$-glukosidase yang telah disarankan dalam pedoman di banyak negara yang memiliki efek samping pada pencernaan seperti diare dan perut kembung [28]. Beberapa studi menunjukkan DNJ tidak memiliki potensi toksiksitas maupun efek mutagenik yang merugikan bila dikonsumsi dalam jangka panjang [29]. Iminosugar DNJ sudah digunakan dan memiliki tingkat keamanan dan tolerabilitas dalam pengobatan penyakit Gaucher yang diakibatkan lysosomal storage disorder maupun non-insulin-dependent diabetes. Studi yang semakin berkembang mengenai pemahaman aktivitas infeksi virus mengampukan pengembangan terapeutik dari DNJ sebagai antiviral potensial untuk pengobatan infeksi virus yang diperlukan [30].

\section{Aktivitas 1- Deoxynojirimycin (DNJ) sebagai Antiviral DENV}

Pada penelitian aktivitas antiviral dengue, DNJ merupakan inhibitor enzim $\alpha$ glukosidase yang efektif untuk menghambat perkembangan replikasi virus [31]. Enzim-enzim $\alpha$-glukosidase menjadi target antivirus karena peran enzim tersebut untuk pengaturan konrol masuk ke jalur the endoplasmic reticulum quality control (ERQC). Kedua jenis enzim $\alpha$ glukosidase, Glul dan Glull, menghilangkan resido glukosa terminal oligosakarida dari N-linked 
glycoprotein dan menghasilkan gula monoglukosilasi. Gula tersebut berfungsi untuk sebagai "tag" pengenalan oleh calnexin dan calreticulin untuk mememediasi capherone yang memungkinkan lipatan $\mathrm{N}$-linked glycoprotein yang tepat. Melalui penghambatan enzim enzim $\alpha$-glukosidase, memungkinkan produksi $\mathrm{N}$-linked glycoprotein untuk amplop virus tidak tepat [32]. Tanpa lipatan glikoprotein yang tepat, infeksivitas dan morfogenesis virus menjadi terganggu [33]

Mekanisme kerja DNJ sebagai inhibitor $\alpha$-glukosidase menunjukkan penurunan sekresi protein $\mathrm{E}$, protein pra-membran dan protein non-struktural melalui penghambatan pada calnexin. Selain itu, DNJ bekerja pada pengurangan calreticulin, calnexin dan rantai berat imunoglobulin sehingga menurunkan produksi dari virus DENV. Aktivitas penghambatan enzim a-glukosidase oleh DNJ dapat ditunjukkan dengan adanya peningkatan oligosakarida bebas/free oligosaccharides (FOS) [34]. FOS merupakan produk akhir dari protein misfolding, dimana pada retikulum endoplasma, DNJ akan menghambat aktivitas enzim glukosidase untuk memecah mannosidase dan pengenalan glikoprotein menjadi gagal terlipat dan melepaskan FOS dalam bentuk Glc1Man4GIcNAc1 dan GIc1Man6GIcNAc1 yang timbul melalui jalur endoplasmic reticulum associated degradation (ERAD) [35]. Mekanisme pemblokiran lipatan glikoprotein virus dapat menghasilkan akumulasi retensi glikoprotein, dimana akan memicu aktivasi unfolded protein response (UPR), yang mana akan menginisiasi faktor respon imun bawaan seperti doublestranded RNA-activated protein kinase (PKR), interferon regulated factor 3 (IRF3), nuclear factor-KB (NF-kB) dan mengurangi infeksi virus [36].

Berdasarkan penelitian yang dilakukan oleh Soyce et al (2016), aktivitas penghambatan enzim $\alpha$-glukosidase retikulum endoplasma melalui peningkatan kadar FOS oleh DNJ lebih tinggi dibandingkan dengan penggunaan celgosivir, salah satu obat antviral yang banyak digunakan. Hasil yang didapat menunjukkan kerja DNJ dalam menghambat kedua enzim $\alpha$-glukosidase sedangkan celgosivir hanya menghambat kerja enzim $\alpha$-glukosidase I pada makrofag yang terinfeksi. Selain bekerja melalui penurunan replikasi virus, DNJ juga bekerja dengan menghambat sekresi virus dari sel inang dengan memperlihatkan kegagalan sekresi virus akibat kegagalan melakukan pelipatan pada retikulum endoplasma mengakibatkan penurunan sekresi virus dari makrofag [34]. Pengurangan kedua enzim $\alpha-$ glukosidase menghasilkan gangguan replikasi virus dan mengurangi pematangan virus yang lebih efektif, sehingga dapat menurunkan viral load dan penularan virus [37].

Aktivitas DNJ juga berperan dalam memodulasi sistem imun untuk merespon aktivitas virus, dimana DENV akan mensupresi interferon tipe I yang beperan dalam aktivasi sitem imun bawaan, sehingga virus DENV dapat bertahan hidup di sel inang [38]. DNJ menstimulasi UPR untuk dapat mengekspresikan malektin yang dapat mempertahankan misfolding di retikulum endoplasma [39]. Malektin mempertahankan aktivitas misfolding glikoprotein virus dengan menghambat calnexin dan calreticulin untuk melakukan pelipatan glikoprotein kembali sehingga glikoprotein menjadi terdegradasi melalui jalur ERAD, yang kemudian akan mengurangi kemajuan sekresi virus dari sel inang [40].

Iminosugar DNJ juga memengaruhi stimulasi sistem imun, yang pada awal infeksi merupakan target lokasi virus DENV untuk bereplikasi, terutama di makrofag yang dapat menekan proses perekrutan sitokin proinflamasi, sehingga memungkinkan virus DENV bereplikasi dalam sel target [32,41]. Virus DENV dapat menghambat molekul respon pensinyalan IFN tipe I melalui mimikri pada protein aktivator transkripsi nuklear untuk mengenali patogen, memungkinkan virus untuk bereplikasi di beberapa sel penghasil IFN-I seperti sel dendritik dan makrofag untuk merespon infeksi pathogen [42]. Pada studi yang dilakukan oleh Miller et al (2019), DNJ dapat meningkatkan jumlah reseptor IFNy dan TNF $\alpha$ dan meningkatkan responsivitas terhadap infeksi melalui respons imun bawaan dan membentuk respons imun adaptif secara cepat sehingga perburukan infeksi dapat dicegah $[43,44]$.

Pada akhirnya, penggunaan DNNJ sebagai antiviral dari virus DENV memengaruhi sifat mematikan dari DENV. Penelitian yang dilakukan oleh Chang et al (2011) menunjukkan 
pada tikus yang diinfeksi dengan DENV memiliki tingkat bertahan hidup yang tinggi dengan menurunkan tingkat viremia hingga 10 kali lipat untuk meningkatkan peluang bertahan hidup dari kemampuan lethal infeksi virus. Kemampuan antiviral dari DNJ dapat menyupresi viremia dari infeksi viral dengue bila dibandingkan pemberian oleh ribavirin [45]. Penelitian yang dilakukan oleh Warfield et al (2020) juga menunjukkan khasiat dari antiviral DNJ dapat menyelamtkan tikus percobaan yang diinfeksi dengan virus dengue setelah 48 jam pasca infeksi. Selain itu, pemberian DNJ juga mengontrol sekresi sitokin proinflamasi yang berperan dalam timbulnya manifestasi klinis dari infeksi DENV, sehingga mengampukan tingkat bertahan hidup yang tinggi terhadap infeksi virus [46].

\section{SIMPULAN}

Infeksi virus DENV yang ditularkan melalui nyamuk merupakan salah satu tantangan kesehatan global. Infeksi virus DENV yang menyebabkan demam dengue, demam berdarah dengue dan dengue syok syndrom menyebabkan angka mortalitas dan morbiditas yang tinggi. Kebutuhan akan terapi antiviral yang efektif menjadi tantangan dalam menghadapi infeksi virus DENV. DNJ merupakan iminosugar yang banyak terdapat pada daun mulberry, bunga matahari, dan beberapa strain bakteri seperti Bacillus, Streptomyces, Actinoplanes, dan Flavobacterium saccharophillium. DNJ telah banyak diteliti dalam terapi obesitas dan diabetes. Aktivitas antiviral DNJ bekerja sebagai penghambat enzim $\alpha$-glukosidase yang efektif untuk menghambat perkembangan replikasi virus DENV sehingga mengurangi sekresi virus dari sel inang, yang mana akan berdampak pada penurunan jumlah produksi virus yang menginfeksi tubuh. Penelitian mengenai aktivitas DNJ sebagai antiviral dengue yang potensial dengan mengurangi tingkat infeksi virus dan meningkatkan kemampuan bertahan hidup subjek terhadap infeksi virus DENV. Penelitian lebih lanjut diperlukan untuk meneliti mengenai metode pengobatan terbaik dan dosis terapi yang aman untuk mengatasi infeksi virus DENV sehingga dapat mengembangkan terapi antiviral DENV yang efektif di masa depan.

\section{PUSTAKA ACUAN}

1. Harapan H, Michie A, Mudatsir M, Sasmono RT, Imrie A. Epidemiology of dengue hemorrhagic fever in Indonesia: Analysis of five decades data from the National Disease Surveillance. BMC Res Notes [Internet]. 2019;12(1):4-9.

2. Low JGH, Ooi EE, Vasudevan SG. Current status of dengue therapeutics research and development. J Infect Dis. 2017;215(Suppl 2):S96-102.

3. Nguyen NM, Kien DTH, Tuan TV, Quyen NTH, Tran CNB, Thi LV, et al. Host and viral features of human dengue cases shape the population of infected and infectious Aedes aegypti mosquitoes. Proc Natl Acad Sci U S A. 2013;110(22):9072-7.

4. Overgaard HJ, Olano VA, Jaramillo JF, Matiz MI, Sarmiento D, Stenström TA, et al. A crosssectional survey of Aedes aegypti immature abundance in urban and rural household containers in central Colombia. Parasites and Vectors. 2017;10(1):1-12.

5. Tuiskunen Bäck A, Lundkvist Å. Dengue viruses - an overview. Infect Ecol Epidemiol. 2013;3(1):19839.

6. Saiz JC, de Oya NJ, Blázquez AB, Escribano-Romero E, Martín-Acebes MA. Host-directed antivirals: A realistic alternative to fight zika virus. Viruses. 2018;10(9).

7. Li DK, Chung RT. Overview of Direct-Acting Antiviral Drugs and Drug Resistance of Hepatitis C Virus. Methods Mol Biol [Internet]. 2019;1911:3-32.

8. Richman DD, Nathanson N. Antiviral Therapy. Viral Pathog. 2016;2016:271-287.

9. Esposito A, D'alonzo D, De Fenza M, De Gregorio E, Tamanini A, Lippi G, et al. Synthesis and therapeutic applications of iminosugars in cystic fibrosis. Int J Mol Sci. 2020;21(9).

10. Chang J, Block TM, Guo JT. Antiviral therapies targeting host ER alpha-glucosidases: Current status and future directions. Antiviral Res [Internet]. 2013;99(3):251-60.

11. Andrade EHP, Figueiredo LB, Vilela APP, Rosa JCC, Oliveira JG, Zibaoui HM, et al. Spatialtemporal co-circulation of dengue virus $1,2,3$, and 4 associated with coinfection cases in 
a hyperendemic area of Brazil: A 4-week survey. Am J Trop Med Hyg. 2016;94(5):1080-4.

12. Rodenhuis-Zybert IA, Wilschut J, Smit JM. Dengue virus life cycle: Viral and host factors modulating infectivity. Cell Mol Life Sci. 2010;67(16):2773-86.

13. Guzman MG, Gubler DJ, Izquierdo A, Martinez E, Halstead SB. Dengue infection. Nat Rev Dis Prim [Internet]. 2016;2:1-26.

14. McLaughlin $M$, Vandenbroeck $K$. The endoplasmic reticulum protein folding factory and its chaperones: New targets for drug discovery? Br J Pharmacol. 2011;162(2):328-45.

15. Srikiatkhachorn A, Mathew A, Rothman AL. Immune-mediated cytokine storm and its role in severe dengue. Semin Immunopathol. 2017;39(5):563-74.

16. Vogt MB, Lahon A, Arya RP, Clinton JLS, Rico-Hesse R. Dengue viruses infect human megakaryocytes, with probable clinical consequences. PLoS NegI Trop Dis. 2019;13(11):123.

17. Sutherland MR, Simon AY, Serrano K, Schubert P, Acker JP, Pryzdial ELG. Dengue virus persists and replicates during storage of platelet and red blood cell units. Transfusion. 2016;56(5):1129-37.

18. Pozzetto B, Memmi M, Garraud O. Is transfusion-transmitted dengue fever a potential public health threat? World J Virol. 2015;4(2):113.

19. Zhang $\mathrm{W}, \mathrm{Mu} \mathrm{W}, \mathrm{Wu} \mathrm{H}$, Liang Z. An overview of the biological production of 1deoxynojirimycin: current status and future perspective. Appl Microbiol Biotechnol. 2019;103(23-24):9335-44.

20. Gao K, Zheng C, Wang T, Zhao H, Wang J, Wang Z, et al. 1-Deoxynojirimycin: Occurrence, extraction, chemistry, oral pharmacokinetics, biological activities and in silico target fishing. Molecules. 2016;21(11).

21. Hu XQ, Thakur K, Chen GH, Hu F, Zhang JG, Zhang H Bin, et al. Metabolic Effect of 1Deoxynojirimycin from Mulberry Leaves on $\mathrm{db} / \mathrm{db}$ Diabetic Mice Using Liquid Chromatography-Mass Spectrometry Based Metabolomics. Vol. 65, Journal of Agricultural and Food Chemistry. 2017. 4658-4667 p.

22. Foucart $Q$, Shimadate $Y$, Marrot J, Kato A, Désiré J, Blériot $Y$. Synthesis and glycosidase inhibition of conformationally locked DNJ and DMJ derivatives exploiting a 2-oxo-C -allyl iminosugar. Org Biomol Chem. 2019;17(30):7204-14.

23. Li YG, Ji DF, Zhong S, Lin TB, Lv ZQ, Hu GY, et al. 1-Deoxynojirimycin Inhibits Glucose Absorption and Accelerates Glucose Metabolism in Streptozotocin-Induced Diabetic Mice. Sci Rep. 2013;3:1-12.

24. Li AN, Chen JJ, Li QQ, Zeng GY, Chen QY, Chen JL, et al. Alpha-glucosidase inhibitor 1Deoxynojirimycin promotes beige remodeling of 3T3-L1 preadipocytes via activating AMPK. Biochem Biophys Res Commun. 2019;509(4):1001-7.

25. Hussain S, Miller JL, Harvey DJ, Gu Y, Rosenthal PB, Zitzmann N, et al. Strain-specific antiviral activity of iminosugars against human influenza $A$ viruses. J Antimicrob Chemother. 2015;70(1):136-52.

26. Stavale EJ, Vu H, Sampath A, Ramstedt U, Warfield KL. In vivo therapeutic protection against influenza a (H1N1) oseltamivir-sensitive and resistant viruses by the iminosugar UV-4. PLoS One. 2015;10(3):1-14.

27. Alonzi DS, Scott KA, Dwek RA, Zitzmann N. Iminosugar antivirals: The therapeutic sweet spot. Biochem Soc Trans. 2017;45(2):571-82.

28. Wang R, Li Y, Mu W, Li Z, Sun J, Wang B, et al. Mulberry leaf extract reduces the glycemic indexes of four common dietary carbohydrates. Med (United States). 2018;97(34).

29. Kothari S, Saravana M, Muthusamy S, Mozingo A, Soni M. Safety assessment of a standardized cucumber extract $\left(\mathrm{Q}-\mathrm{Actin}^{\mathrm{TM}}\right)$ : Oral repeat-dose toxicity and mutagenicity studies. Toxicol Reports [Internet]. 2018;5(August):1078-86.

30. Tyrrell BE, Sayce AC, Warfield KL, Miller JL, Zitzmann N. Iminosugars: Promising therapeutics for influenza infection. Crit Rev Microbiol. 2017;43(5):521-45.

31. Howe JD, Smith N, Lee MJR, Ardes-Guisot N, Vauzeilles B, Désiré J, et al. Novel imino sugar 
$\alpha$-glucosidase inhibitors as antiviral compounds. Bioorganic Med Chem [Internet]. 2013;21(16):4831-8.

32. Kiappes JL, Hill ML, Alonzi DS, Miller JL, Iwaki R, Sayce AC, et al. ToP-DNJ, a Selective Inhibitor of Endoplasmic Reticulum $\alpha$-Glucosidase II Exhibiting Antiflaviviral Activity. ACS Chem Biol. 2018;13(1):60-5.

33. Zhao X, Guo F, Comunale MA, Mehta A, Sehgal M, Jain P, et al. Inhibition of endoplasmic reticulum-resident glucosidases impairs severe acute respiratory syndrome coronavirus and human coronavirus NL63 spike protein-mediated entry by altering the glycan processing of angiotensin I-converting enzyme 2. Antimicrob Agents Chemother. 2015;59(1):206-16.

34. Sayce AC, Alonzi DS, Killingbeck SS, Tyrrell BE, Hill ML, Caputo AT, et al. Iminosugars Inhibit Dengue Virus Production via Inhibition of ER Alpha-Glucosidases-Not Glycolipid Processing Enzymes. PLoS Negl Trop Dis. 2016;10(3):1-22.

35. Alonzi DS, Kukushkin N V., Allman SA, Hakki Z, Williams SJ, Pierce L, et al. Glycoprotein misfolding in the endoplasmic reticulum: Identification of released oligosaccharides reveals a second ER-associated degradation pathway for Golgi-retrieved proteins. Cell Mol Life Sci. 2013;70(15):2799-814.

36. Diwaker D, Mishra KP, Ganju L. Effect of modulation of unfolded protein response pathway on dengue virus infection. Acta Biochim Biophys Sin (Shanghai). 2015;47(12):960-8.

37. Bhushan G, Lim L, Bird I, Chothe SK, Nissly RH, Kuchipudi S V. Iminosugars With Endoplasmic Reticulum $\alpha$-Glucosidase Inhibitor Activity Inhibit ZIKV Replication and Reverse Cytopathogenicity in vitro. Front Microbiol. 2020;11(February 2016):1-15.

38. Chan CYY, Low JZH, Gan ES, Ong EZ, Zhang SL-X, Tan HC, et al. Antibody-Dependent Dengue Virus Entry Modulates Cell Intrinsic Responses for Enhanced Infection. mSphere. 2019;4(5).

39. Takeda K, Qin SY, Matsumoto N, Yamamoto K. Association of malectin with ribophorin I is crucial for attenuation of misfolded glycoprotein secretion. Biochem Biophys Res Commun [Internet]. 2014;454(3):436-40.

40. O'Keefe S, Roebuck QP, Nakagome I, Hirono S, Kato A, Nash R, et al. Characterizing the selectivity of ER $\alpha$-glucosidase inhibitors. Glycobiology. 2019;29(7):530-42.

41. St. John AL, Rathore APS. Adaptive immune responses to primary and secondary dengue virus infections. Nat Rev Immunol [Internet]. 2019;19(4):218-30.

42. Gack MU, Diamond MS. Innate immune escape by Dengue and West Nile viruses. Curr Opin Virol. 2016;20(October):119-128.

43. Miller JL, Hill ML, Brun J, Pountain A, Sayce AC, Zitzmann N. Iminosugars counteract the downregulation of the interferon $\gamma$ receptor by dengue virus. Vol. 170, Antiviral Research. 2019.

44. Castillo Ramirez JA, Urcuqui-Inchima S. Dengue Virus Control of Type i IFN Responses: A History of Manipulation and Control. J Interf Cytokine Res. 2015;35(6):421-30.

45. Chang J, Schul W, Yip A, Xu X, Guo JT, Block TM. Competitive inhibitor of cellular $\alpha$ glucosidases protects mice from lethal dengue virus infection. Antiviral Res [Internet]. 2011;92(2):369-71.

46. Warfield KL, Alonzi DS, Hill JC, Caputo AT, Roversi P, Kiappes JL, et al. Targeting Endoplasmic Reticulum $\alpha$-Glucosidase i with a Single-Dose Iminosugar Treatment Protects against Lethal Influenza and Dengue Virus Infections. J Med Chem. 2020;63(8):4205-14. 